\title{
Aplikasi Penderiaan Jauh atau Remote Sensing dalam Pemodelan Pengaruh Iklim terhadap Taburan Burung Hijrah Di Hutan Paya Laut Matang, Perak
}

Azimah Abd Rahman*

Pusat Pengajian Sains Kajihayat, Universiti Sains Malaysia, 11800 Penang, Malaysia

*Corresponding author: azimahrahman@usm.my

\begin{abstract}
Climate changes especially temperature and rainfall effect the habitat selection of bird migration in mangrove area to get some food and temporary stopover. The increase and decrease of temperature and rainfall is varies between upstream to downstream. This research was done to prove that temperature and rainfall are uneven in some area even in same boundary that can give impact in habitat selection of migratory birds. This research was concern around Matang Mangrove Forest, Perak that already familiar as focal area for migratory birds. Remote Sensing application was used in this research through use of ERDAS Imagine 8.5 which is based on pixels. This application helps to model the relationship between climate, namely temperature and rainfall with distribution density of migratory birds around the study area. Climate modeling was conducted to predict the distribution of migratory bird populations in the future due to changes in temperature and rainfall over a period of 5 years and 20 years. The results of this study showed a decrease in the population of migratory birds by $6.4 \%$ for a period of 5 years and a decrease to $7.5 \%$ for the last 20 years. Sungai Sepetang and Sungai Selinsing shown that migratory bird populations decreased continuously after 20 years. However the Sangga Besar, Teluk Kertang, Temerlok, Pulau Pasir Hitam dan Sungai Tinggi area showed an increase in the arrival of migratory birds after 20 years. This information analysis help the related agencies in manage and maintain the area around the Matang Mangrove Forest identified potential habitat for migratory birds in the future. In addition, through this study migratory bird monitoring can be carried out systematically on a wider scope without ignoring areas that strives to be the alternative habitat for migratory birds in the future.
\end{abstract}

Keywords: Remote sensing, climate model, temperature, rainfall, migratory bird, matang mangrove forest

\begin{abstract}
Abstrak
Perubahan iklim terutamanya suhu dan taburan hujan mempengaruhi pemilihan habitat bagi burung hijrah di kawasan paya bakau untuk mendapatkan makanan dan ruang rehat sementara. Peningkatan dan penurunan suhu serta taburan hujan adalah berbeza-beza di antara kawasan hulu ke muara sungai. Kajian ini dilakukan bagi membuktikan suhu dan taburan hujan adalah tidak sekata bagi sesuatu kawasan walaupun berada pada sempadan sama yang secara tidak langsung memberi impak kepada pemilihan habitat burung hijrah. Tumpuan kajian adalah di sekitar kawasan Hutan Paya Laut Matang, Perak yang menjadi tumpuan burung berhijrah. Aplikasi Penderiaan Jauh digunakan dalam kajian ini melalui penggunaan perisian ERDAS Imagine 8.5 yang berasaskan piksel. Aplikasi ini membantu memodelkan hubungan antara iklim iaitu suhu dan taburan hujan dengan kepadatan taburan burung hijrah sekitar kawasan kajian. Pemodelan iklim dilakukan untuk meramalkan keadaan taburan populasi burung hijrah pada masa akan datang akibat perubahan suhu dan taburan hujan bagi tempoh 5 tahun dan 20 tahun akan datang. Hasil kajian ini menunjukkan penurunan populasi burung hijrah sebanyak $6.4 \%$ bagi tempoh 5 tahun dan semakin menurun kepada $7.5 \%$ bagi tempoh 20 tahun akan datang. Sungai Sepetang dan Sungai Selinsing menunjukkan penurunan populasi burung hijrah secara berterusan selepas 20 tahun. Namun begitu kawasan Sangga Besar, Teluk Kertang, Temerlok, Pulau Pasir Hitam dan Sungai Tinggi menunjukkan peningkatan kedatangan burung hijrah selepas 20 tahun. Maklumat analisis kajian ini membantu agensi yang berkaitan dalam mengurus dan memelihara kawasan sekitar Hutan Paya Laut Matang yang dikenalpasti berpotensi menjadi habitat burung hijrah pada masa akan datang. Selain itu, melalui kajian ini pemantauan burung hijrah dapat dilakukan secara bersistematik pada skop kawasan yang lebih luas tanpa mengabaikan kawasan yang berupaya menjadi lokasi habitat alternatif bagi burung hijrah pada masa hadapan.
\end{abstract}

Kata Kunci : Penderiaan jauh, model iklim, suhu, hujan, burung hijrah, hutan paya laut matang

(C) 2016 Penerbit UTM Press. All rights reserved

\subsection{PENGENALAN}

Kedatangan spesis burung air yang berhijrah dari negara luar atau lebih dikenali sebagai burung hijrah yang tertumpu di kawasan Hutan Paya Bakau di Malaysia menarik perhatian penyelidik serta pencinta alam dari pelbagai negara. Burung hijrah dilihat mempunyai nilai komersial tersendiri dan potensi yang tinggi terutamanya dalam tarikan pelancongan yang terbaru di Malaysia (Moore et al., 2005). Antaranya kawasan Hutan Paya Laut Matang yang menerima kedatangan pelancong dari dalam dan luar setelah kawasan ini diisytiharkan sebagai lokasi perlindungan spesis burung air termasuk pelbagai spesis burung hijrah (Jamaluddin Md. Jahi, 2009).

Namun begitu gangguan terhadap kawasan persekitaran terutamanya terhadap liputan tanah dan gunatanah seperti aktiviti pembalakan, agrikultur dan pembangunan petempatan secara tidak langsung mengubah iklim iaitu suhu dan taburan hujan sekitar kawasan ini. Perubahan iklim memberi impak kepada spesis burung hijrah yang sangat sensitif terhadap perubahan persekitaran mereka dalam 
pemilihan habitat (Howes et al., 2005). Perubahan iklim walaupun pada kadar yang kecil memberi kesan secara tidak langsung terhadap pasang surut air laut yang mempengaruhi keadaan tebing dan kawasan intertidal khususnya yang menjadi tumpuan burung hijrah untuk mendapatkan bekalan makanan dan ruang rehat semasa migrasi. Kajian terdahulu mendapati pertambahan suhu pada kadar antara $1.4 \mathrm{C}^{\circ}$ hingga $5.8 \mathrm{C}^{\circ}$ memberi kesan kepada kemusnahan terhadap habitat burung dikawasan intertidal (Galbraith et al., 2001).

Menyedari potensi burung hijrah di kawasan Hutan Paya Laut Matang, beberapa agensi yang berkaitan seperti Jabatan Perhilitan dan Jabatan Perhutanan berusaha melaksanakan program pemeliharaan dan pemuliharaan terutamanya terhadap kawasan Hutan Paya Bakau itu sendiri yang berperanan penting sebagai habitat burung hijrah. Beberapa parameter diberi tumpuan dalam hal ini termasuk perubahan iklim persekitaran. Namun begitu, pelaksanaan program yang bersifat konventional iaitu penggunaan kaedah manual menyebabkan usaha pemeliharaan dan pemuliharaan habitat burung hijrah gagal dilaksanakan. Saban tahun kawasan Hutan Paya Laut Matang mengalami penurunan kedatangan burung hijrah yang semakin membimbangkan dengan anggaran antara $75 \%$ hingga $95 \%$ bagi jangkamasa 10 tahun akan datang (Li et al., 2009).

Pemilihan pendekatan dan teknik yang bersesuaian adalah diperlukan bagi menentukan kesan iklim terhadap taburan populasi burung hijrah bagi menjamin kejayaan program pemeliharaan dan pemuliharaan terhadap paya bakau yang dilaksanakan (Gauthreaux dan Belser, 2003). Kaedah berasaskan konsep ruangan atau spatial merupakan pendekatan yang paling sesuai untuk dipraktikan sebagai amalan kerja dalam kajian ini. penggunaan aplikasi sistem maklumat geografi dan penderiaan jauh mampu memperbaiki amalan kerja dan analisis yang telah diamalkan sebelum ini (Peterson, 2001).

Tidak dinafikan terdapat pelbagai kajian terdahulu yang berkaitan burung hijrah telah dilaksanakan melalui penggunaan aplikasi GIS dan penderiaan jauh khususnya dalam mengenalpasti corak dan pola taburan burung hijrah,arah pergerakan burung hijrah, lokasi tumpuan burung hijrah dan lain-lain. Namun begitu kebanyakan kajian lebih menumpukan kepada kaedah analisis titik (point pattern analysis) yang memberi hasil analisis yang kurang tepat (Shao dan Wu, 2008). Analisis titik tidak sesuai untuk mengukur kesan iklim terhadap taburan populasi burung hijrah kerana kesan iklim yang lebih menyeluruh dan tidak boleh ditentukan berasaskan sempadan yang tertentu sahaja (Tankersley dan Orvis, 2003). Dalam kajian ini, penggunaan aplikasi penderiaan jauh memodelkan iklim menggunakan pendekatan berasaskan piksel bersesuaian dengan keluasan keseluruhan kawasan kajian bagi memperoleh hasil analisis yang lebih tepat.

\subsection{METODOLOGI KAJIAN}

\subsection{Kawasan Kajian}

Pemodelan iklim ini melibatkan keseluruhan kawasan Hutan Paya Laut Matang yang berkeluasan 101,877 hektar. Kawasan Hutan Paya Bakau ini mempunyai 198 Hutan Simpan Kekal yang menyediakan habitat bagi pelbagai spesis flora dan fauna termasuk burung hijrah. Selain itu, hutan ini juga terdapat beberapa tarikan ecopelancongan seperti Hutan Simpanan Dara (Virgin Jungle Reserve), kawasan proto sejarah di Pulau Kelumpang, Hutan Pelajaran dan Penyelidikan (Eko-Pelajaran), aktiviti menangkap kerang, dapur arang kayu, perkampungan nelayan dan penternakan ikan dalam sangkar oleh komuniti tempatan (Rajah 1).

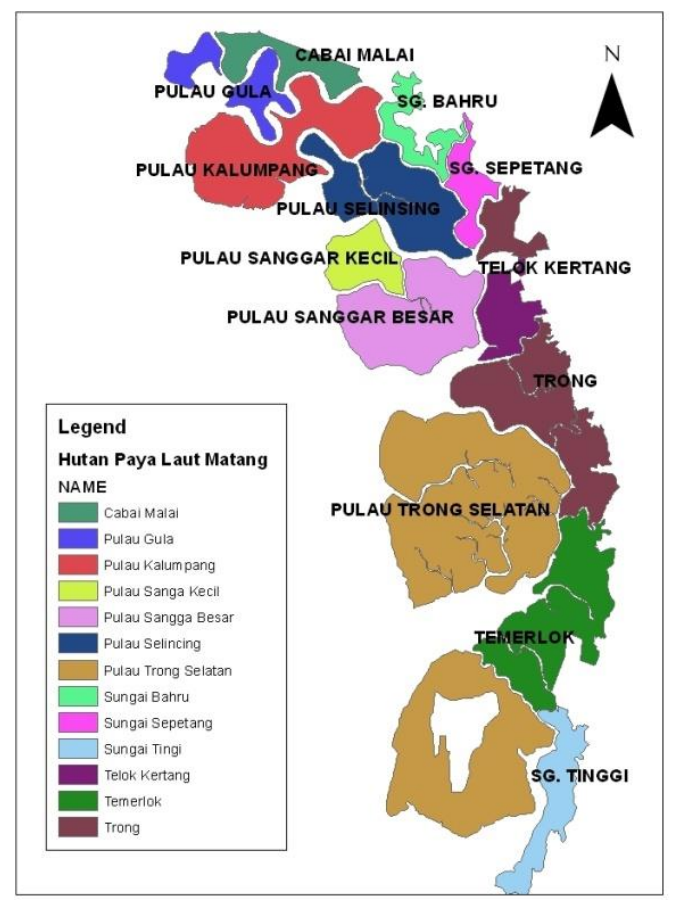

Rajah 1 Hutan Paya Laut Matang, Perak 
Bagi tujuan kajian ini, terdapat 10 stesen telah ditetapkan bagi tujuan pensampelan burung hijrah yang meliputi kawasan Pulau Kalumpang, Pulau Trong, Pulau Pasir Hitam dan beberapa pulau kecil yang mengelilingi hutan ini. Pemilihan stesen ini adalah berasaskan berasaskan rekod pemerhatian kedatangan burung hijrah oleh Jabatan Perhilitan Daerah Matang bagi tahun 2000 hingga 2009 (Jadual 1).

Jadual 1 Kawasan penjaringan dan pemantauan burung hijrah

\begin{tabular}{ll}
\hline Kawasan Tumpuan & Bilangan Burung \\
\hline Kuala Gula & 200,556 \\
Kuala Selinsing & 77,723 \\
Kelumpang & 108.013 \\
Tasik Kelumpang & 71,164 \\
Tasik Trong & 46,644 \\
Parit Besar & 16,696 \\
Sungai Burung & 29,532 \\
Pantai Remis & 65,470 \\
Sungai Tiang & 32,532 \\
Sangga Besar & 49,227 \\
\hline
\end{tabular}

\subsection{Perolehan Data Kajian}

\subsubsection{Kajian Lapangan}

Kajian lapangan dilakukan khususnya bagi kutipan data berkaitan burung hijrah. Kaedah pensampelan burung hijrah menggunakan jaring kabut (mist net) yang banyak digunakan dalam kajian terdahulu yang melibatkan spesis burung termasuk burung hijrah kerana mudah digunakan tanpa mencederakan burung yang terperangkap (Wang dan Finch, 2002). Dalam kajian ini mata jaring berukuran 1.5 inci atau $37 \mathrm{~mm}$ hingga $44 \mathrm{~mm}$ telah digunakan bersesuaian dengan saiz burung hijrah yang berukuran antara $12 \mathrm{~cm}$ hingga $66 \mathrm{~cm}$. Pemasangan jaring dilakukan secara mendatar dengan kelebaran 6 meter dan tinggi 2 meter dilakukan bersesuaian dengan tinggi pasang surut air laut di kawasan ini (Rajah 2).

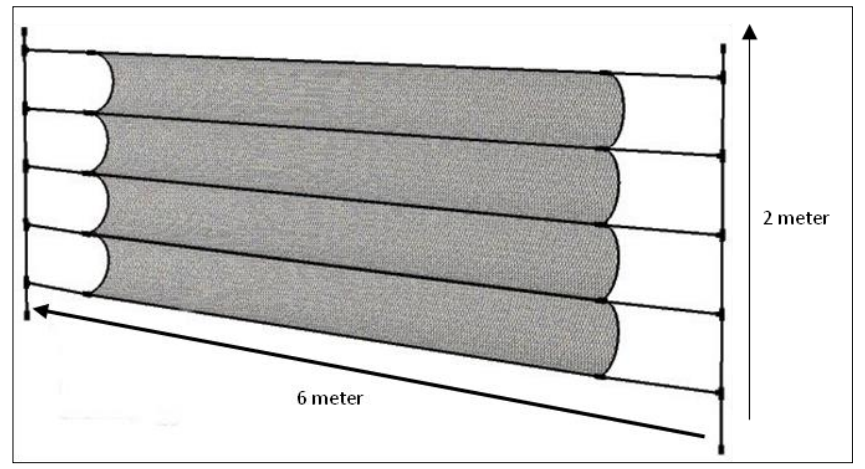

Rajah 2 Cara pemasangan Jaring Kabut

Pemasangan jaring dilakukan pada awal pagi iaitu seawal 8.30 pagi hingga 12.30 tengahari mengikut keadaan pasang surut air laut bagi memudahkan pergerakan bot. Pemantauan terhadap jaring dilakukan setiap 2 jam hingga 3 jam bagi mengelakkan burung yang terperangkap mati, cedera atau berjaya membebaskan diri. Hasil jaringan akan direkodkan secara bertulis menggunakan borang yang disediakan khas oleh Jabatan Perhilitan yang mengandungi butiran lengkap berkaitan burung hijrah seperti maklumat spesis, keluarga, saiz tubuh, ciri-ciri morfologi burung hijrah, tarikh tangkapan, kepadatan, habitat dan lokasi tangkapan (Rajah 3).

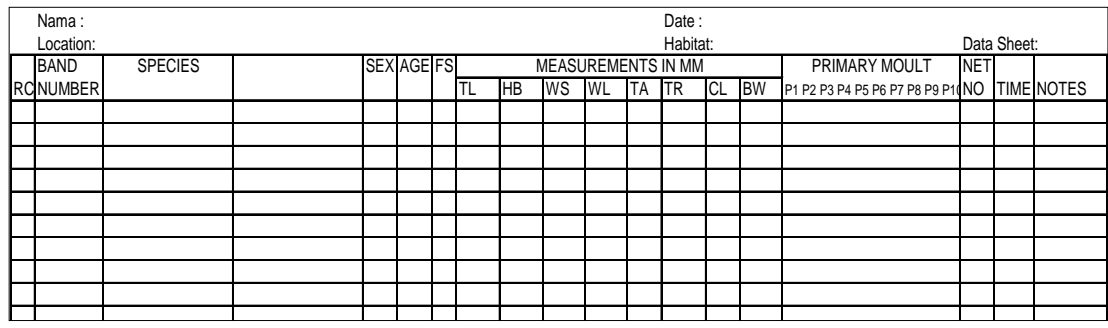

Rajah 3 Borang merekod burung 
Aktiviti menjaring dilakukan secara berkala setiap kali musim hijrah yang berlaku sepanjang September hingga April setiap tahun. Penangkapan burung hijrah dalam kajian ini menggunakan konsep tangkap tanda dan tangkap semula yang dilakukan sebanyak tiga sesi yang mengambil masa dua minggu bagi setiap sesi (Jadual 2).

Jadual 2 Sesi penangkapan mengikut musim hijrah

\begin{tabular}{ll}
\hline Bilangan sesi & Jangkamasa \\
\hline Sesi Pertama & Ogos hingga Oktober \\
Sesi Kedua & November hingga Februari \\
Sesi Ketiga & Mac hingga Mei \\
\hline
\end{tabular}

\subsubsection{Data Sekunder}

Kebanyakan data yang digunakan dalam kajian ini adalah menggunakan data sekunder yang diperolehi daripada pelbagai agensi yang terlibat secara langsung mahupun secara tidak langsung seperti Jabatan Perhilitan dan Jabatan Perhutanan, Jabatan Ukur dan Pemetaan Malaysia (JUPEM), Jabatan Meteorologi, Jabatan perhilitan serta agensi sokongan lain seperti Wetlands International turut digunakan dalam kajian ini (Jadual 3).

Jadual 3 Data ruangan dan atribut yang digunakan dalam kajian

\begin{tabular}{|c|c|c|c|}
\hline Senarai Data & Sumber Data & Format Data & Tahun \\
\hline Lokasi Kawasan Kajian & Majlis Daerah Kerian & Ruangan & $2000-2009$ \\
\hline Data Burung Hijrah & $\begin{array}{c}\text { Jabatan Perhilitan dan hidupan liar, } \\
\text { Kuala Gula }\end{array}$ & Ruangan & 2000-2009 \\
\hline Data Fauna & $\begin{array}{l}\text { Jabatan Perhilitan dan hidupan liar, } \\
\text { Kuala Gula }\end{array}$ & Ruangan & 2000-2009 \\
\hline Data Kawasan Menjaring & $\begin{array}{l}\text { Jabatan Perhilitan dan hidupan liar, } \\
\text { Kuala Gula }\end{array}$ & Ruangan & 2000-2009 \\
\hline Data Aktiviti Ekonomi & $\begin{array}{c}\text { Jabatan perancang bandar dan desa } \\
\text { daerah kerian }\end{array}$ & Ruangan & 2000-2009 \\
\hline Data Suhu & Jabatan Meteorologi Malaysia & Ruangan & 2000-2009 \\
\hline Data Hujan & Jabatan Meteorologi Malaysia & Ruangan & $2000-2009$ \\
\hline Data Sungai & Jabatan Perhutanan Malaysia & Bukan Ruangan & $2000-2009$ \\
\hline Data Sempadan & Jabatan Perhutanan Malaysia & Atribut & $2000-2009$ \\
\hline Data Ketinggian & Jabatan Perhutanan Malaysia & Atribut & $2000-2009$ \\
\hline Data Kompartment Hutan & $\begin{array}{c}\text { Jabatan Perhutanan Daerah Larut } \\
\text { Matang }\end{array}$ & Atribut & 2000-2009 \\
\hline Data Jenis Hutan & $\begin{array}{c}\text { Jabatan Perhutanan Daerah Larut } \\
\text { Matang }\end{array}$ & Atribut & 2000-2009 \\
\hline Data Sempadan Hutan & $\begin{array}{c}\text { Jabatan Perhutanan Daerah Larut } \\
\text { Matang }\end{array}$ & Atribut & 2000-2009 \\
\hline
\end{tabular}

\subsubsection{Penyediaan Data Iklim}

Dalam penyediaan data iklim bagi kajian ini, kebanyakan data iklim diperolehi melalui stesen kajicuaca dikawasan yang berhampiran iaitu kawasan Lumut dan Bukit Larut. Namun begitu data yang terhad menyebabkan pengaruh suhu dan taburan hujan tidak dapat dimodelkan secara tepat dan menyeluruh. Data satelit yang berasaskan piksel telah digunakan dalam kajian ini iaitu data MODIS (Moderate-resolution Imaging Spectroradiometer) dan TRMM (Tropical Rainfall Measuring Mission).Data MODIS menunjukkan suhu permukaan bagi kawasan kajian berasaskan kelembapan persekitarannya berasaskan kutipan data suhu bulanan pada resolusi $150 \mathrm{~m}$ persegi. Sementara data TRMM mengandungi himpunan hujan tahunan bagi tempoh 10 tahun yang ditunjukkan melalui hasil peta taburan hujan dengan resolusi $100 \mathrm{~m}$ persegi.

Bagi tujuan pemodelan iklim, saiz piksel bagi data MODIS dan TRMM telah diselaraskan kepada 50m persegi bersesuaian dengan saiz pecahan grid setiap stesen jaringan dalam kajian ini. Penggunaan saiz ini adalah sesuai keluasan keseluruhan setiap stesen jaringan burung sebesar $500 \mathrm{~m}$ persegi. Penetapan saiz piksel ini dilakukan dengan bantuan perisian ERDAS Imagine 8.5 yang sesuai dalam pengurusan data dalam bentuk piksel.

\subsection{PEMODELAN IKLIM}

Dalam kajian ini pemodelan iklim yang melibatkan kesan perubahan suhu dan taburan hujan terhadap corak taburan burung hijrah. Pembinaan model iklim ini melibatkan empat fasa utama yang meliputi penetapan pembolehubah, pemprosesan data, pelaksanaan model dan juga pengujian hasil analisis model (Rajah 4). 


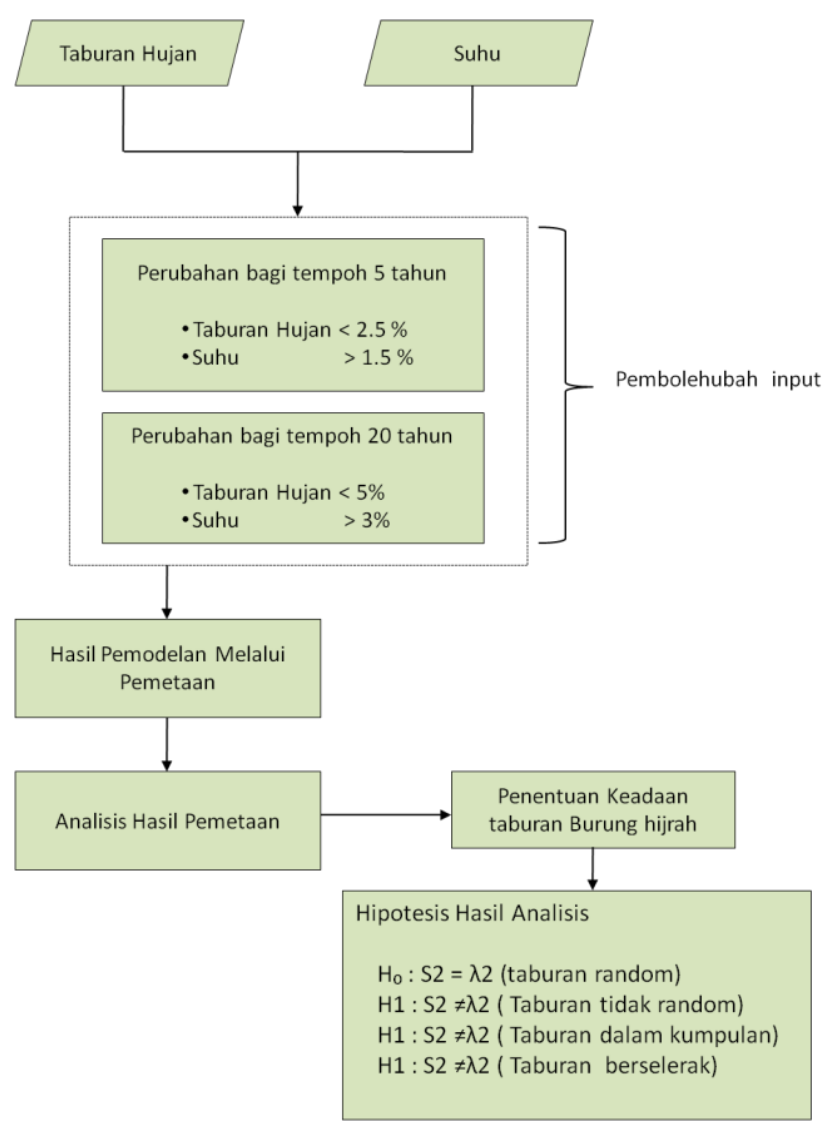

Rajah 4 Aliran kerja pemodelan iklim

\subsection{Penetapan Pembolehubah}

Pemodelan iklim dalam kajian ini melibatkan ramalan keadaan taburan dan kepadatan populasi burung hijrah kesan perubahan suhu dan taburan hujan bagi jangkamasa 5 tahun dan 20 tahun akan datang. Dalam hal ini, pembolehubah model telah ditetapkan berasaskan kepada peningkatan dan penurunan suhu dan taburan hujan bagi jangkamasa 5 tahun dan 20 tahun berasaskan kepada General Circulation Model (GCM) yang telah dibina dibawah sokongan Intergovernmental Panel on Climate Change (IPCC). Melalui maklumat GCM, peningkatan suhu tahunan bagi 5 tahun akan datang adalah sebanyak $0.25^{\circ} \mathrm{C}$ dengan peningkatan hujan tahunan sebanyak $0.035 \mathrm{~mm}$. Sementara peningkatan suhu tahunan meningkat sehingga $1{ }^{\circ} \mathrm{C}$ dengan peningkatan taburan hujan sebanyak $0.14 \mathrm{~mm}$ menjelang 20 tahun akan datang.

Berasaskan maklumat GCM ini, pembolehubah model iklim ditetapkan iaitu perubahan suhu pada julat antara $1.5 \%$ hingga $4.5 \%$ per dekad serta perubahan taburan hujan bagi jangkamasa 10 tahun yang berubah dari $2.5 \%$ hingga $6.5 \%$ pada jangkamasa yang sama. Penetapan ini menjadi syarat bagi input elemen iklim yang digunakan dalam pemodelan iklim bagi kajian ini (Jadual 4).

Jadual 4 Pembolehubah model iklim

\begin{tabular}{|l|l|l|}
\hline \multirow{2}{*}{ Parameter } & Prasyarat Parameter \\
\cline { 2 - 3 } & 5 tahun & 20 tahun \\
\cline { 1 - 1 } Suhu & $1.50 \%$ & $3 \%$ \\
\cline { 1 - 1 } Taburan Hujan & $2.50 \%$ & $5 \%$ \\
\hline
\end{tabular}

\subsection{Pelaksanaan Model}

\subsubsection{Pemetaan Hasil Pemodelan Iklim}

Bagi pemetaan model iklim, setiap parameter iklim di hubungkan dengan kepadatan populasi burung dalam bentuk diagram yang boleh ditetapkan mengikut keperluan kajian. Bagi kajian ini sebanyak lima tahap hubungan telah dibentuk iaitu sangat rendah, rendah, sederhana, tinggi dan sangat tinggi. Pelaksanaan pemetaan suhu dan taburan hujan dalam kajian ini adalah menggunakan data berasaskan piksel iaitu melalui penggunaan data MODIS dan TRMM. 
Oleh itu setiap data suhu dan taburan hujan diwakilkan menggunakan warna yang menunjukkan kadar suhu dan taburan hujan dalam kawasan kajian. Perwakilan warna membolehkan perbezaan penyebaran suhu dan taburan hujan sekitar kawasan Hutan Paya Laut Matang bagi tempoh 5 tahun dan 20 tahun akan datang dikenalpasti (Jadual 5)

Jadual 5 Penetapan perwakilan setiap piksel

\begin{tabular}{llll}
\hline Suhu $\left(\mathbf{C}^{\circ}\right)$ & Perwakilan & Hujan $(\mathbf{m m})$ & Perwakilan \\
\hline $17-20$ & & $1110-1134$ & \\
$20-24$ & $1135-1159$ & \\
$24-26$ & $1159-1195$ & \\
$26-28$ & $1195-1222$ & \\
$>29$ & $1222-1223$ & \\
& & $1224-1256$ & \\
& $>1256$ & \\
\hline
\end{tabular}

Pembolehubah yang telah ditetapkan bagi setiap parameter iklim dihubungkan dengan kadar kepadatan setiap parameter menggunakan perisian ERDAS Imagine 8.5 melalui kefungsian Classifier yang terdapat dalam aplikasi Knowlegde Engineer dalam perisian ini. Pelaksanaan model kemudiannya dilakukan menggunakan fungsi modeler setelah pemprosesan pembolehubah dilakukan. Aplikasi Function Definition yang terdapat dibawah kefungsian ini berperanan menghubungkaitkan antara pembolehubah iklim yang telah ditetapkan sebagai contoh hubungan antara suhu dengan taburan populasi burung hijrah bagi tempoh 5 tahun (Rajah 5 ).

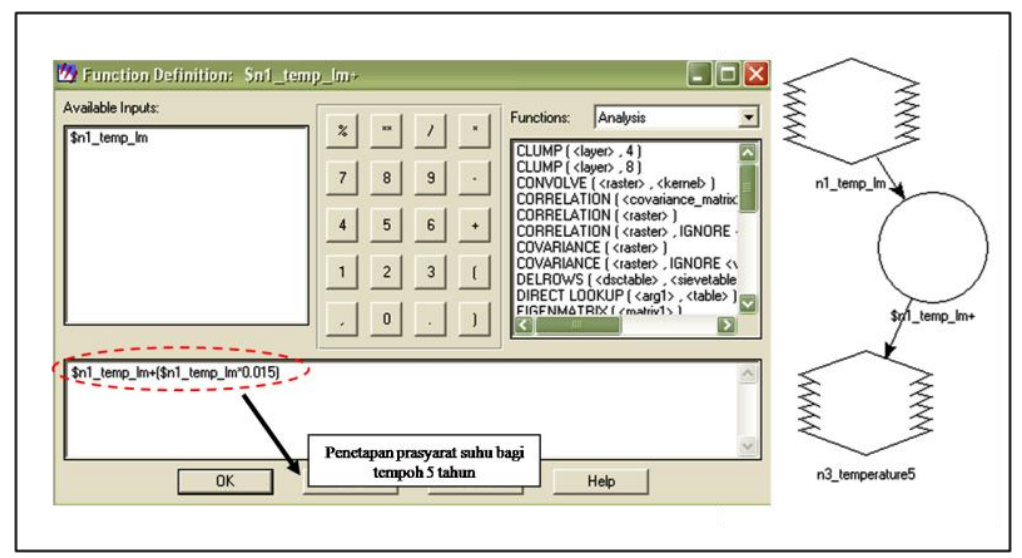

Rajah 5 Pemodelan input suhu bagi 5 tahun

\subsubsection{Penentuan Corak Taburan Burung Hijrah}

Melalui hasil pemetaan yang dihasilkan melalui model iklim, kesan perubahan suhu dan taburan hujan terhadap corak taburan burung hijrah bagi tempoh 5 tahun dan 20 tahun akan datang dapat ditunjukkan. Namun begitu, jenis corak taburan burung hijrah bagi kawasan kajian sama ada berselerak, berkelompok mahupun random tidak dapat ditentukan secara tepat.

Penentuan jenis corak taburan burung hijrah adalah penting bagi menentukan arah taburan burung hijrah bagi meramalkan potensi sesuatu kawasan sebagai habitat bagi burung hijrah. Dalam kajian ini Moran I, telah digunakan kerana sesuai untu diaplikasikan bersama data titik mahupun data piksel. Moran I, menumpukan kepada corak taburan sama ada secara sekata mahupun tidak sekata dalam setiap sempadan kawasan kajian. Nilai kritikal yang diperolehi melalui kaedah Moran I iaitu antara -1.96 dan +1.96 dapat menentukan corak taburan burung hijrah di kawasan kajian.

\subsection{HASIL ANALISIS DAN PERBINCANGAN}

\subsection{Kesan Perubahan Iklim terhadap Kepadatan Burung Hijrah}

Menggunakan pendekatan aplikasi GIS dan penderiaan jauh model iklim yang dihasilkan mampu meramalkan pengaruh iklim terhadap kepadatan populasi burung hijrah di kawasan kajian. Kajian ini menumpukan kepada ramalan perubahan suhu dan taburan hujan bagi jangkamasa 5 tahun dan 20 tahun. Bagi tempoh 5 tahun, kepadatan burung hijrah dikawasan Pulau Kalumpang menurun dari kepadatan 422 ekor per $50 \mathrm{~m}^{2}$ kepada 274 ekor per $50 \mathrm{~m}^{2}$. Situasi yang sama turut berlaku di Pulau Trong yang mengalami penurunan yang drastik iaitu dari kepadatan purata sebanyak 422 ekor per $50 \mathrm{~m}^{2}$ kepada serendah 25 ekor per $50 \mathrm{~m}^{2}$ pada tahun yang sama. Namun begitu selepas 20 
tahun kawasan Pulau Trong kembali menjadi lokasi tumpuan bagi burung hijrah purata kepadatan sebanyak 274 ekor per $50 \mathrm{~m}^{2}$ dihampir keseluruhan kawasan ini (Jadual 6).

Jadual 6 Kadar perubahan kepadatan taburan burung hijrah

\begin{tabular}{|l|l|l|l|}
\hline Stesen Jaringan & $\mathbf{2 0 0 9}$ & $\mathbf{5}$ tahun & $\mathbf{2 0}$ tahun \\
\hline Cabai Malai & 238 & 140 & 142 \\
\hline Kertang & 122 & 152 & 175 \\
\hline Kuala Gula & 275 & 154 & 168 \\
\hline Pasir Hitam & 246 & 244 & 165 \\
\hline Pulau Kelumpang & 318 & 224 & 224 \\
\hline Sangga Besar & 170 & 198 & 191 \\
\hline Sangga Kecil & 185 & 206 & 164 \\
\hline Selinsing & 213 & 154 & 139 \\
\hline Sepetang & 185 & 161 & 142 \\
\hline Sg. Baru & 154 & 160 & 147 \\
\hline Sg. Tinggi & 160 & 151 & 110 \\
\hline Temerlok & 219 & 164 & 153 \\
\hline Trong & 159 & 183 & 153 \\
\hline Trong Selatan & 240 & 134 & 194 \\
\hline
\end{tabular}

Terdapat juga kawasan yang tidak mengalami sebarang perubahan bagi tempoh 5 tahun dan juga 20 tahun iaitu kawasan Pulau Pasir Hitam. Sementara kawasan seperti Cabai Malai, Sungai Bahru, Sungai Sepetang dan juga Pulau Kalumpang menunjukkan perubahan kepadatan burung hijrah yang tetap bagi tahun ke 5 hingga tahun ke 20 (Rajah 6).

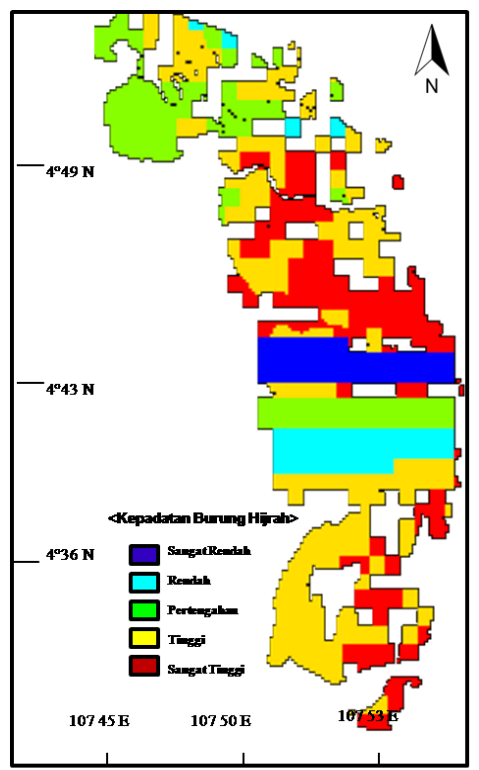

5 Tahun

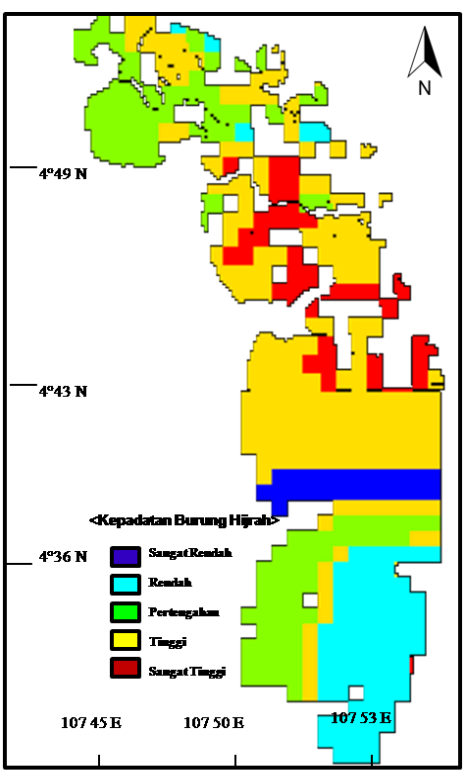

20 Tahun

Rajah 6 Pemetaan perubahan iklim untuk 5 tahun dan 20 tahun

Hasil pemodelan iklim juga menunjukkan perubahan kepadatan taburan burung hijrah secara keseluruhan bagi tempoh 5 tahun dan 20 tahun juga dapat dikenalpasti. Penurunan sebanyak 2588 ekor atau $6.4 \%$ diramalkan bagi tempoh 5 tahun sementara 3012 ekor atau bersamaan $7.5 \%$ diramalkan selepas tempoh 20 tahun (Rajah 7). 


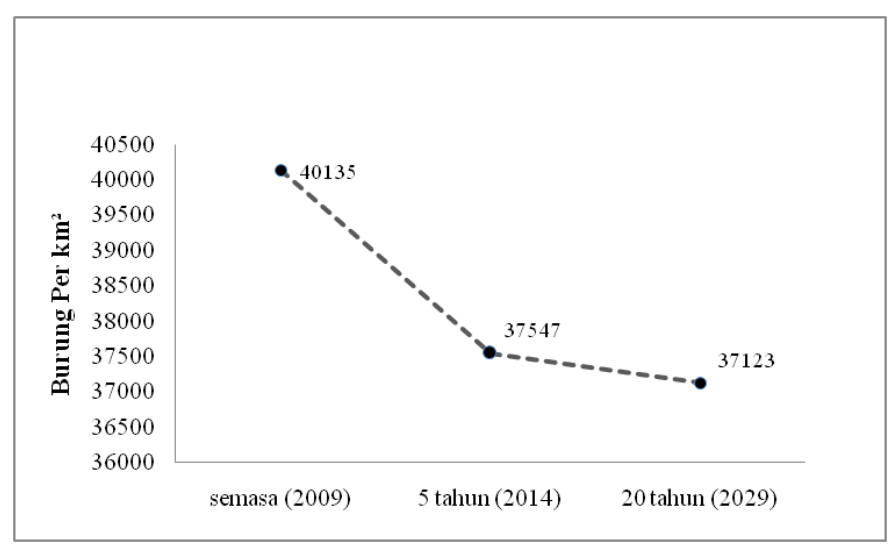

Rajah 7 Kepadatan burung hijrah bagi tempoh 5 tahun dan 20 tahun

\subsection{Sensitiviti Kawasan Kajian}

Melalui model iklim yang telah dihasilkan arah tumpuan burung hijrah sekitar kawasan Hutan Paya Laut Matang kesan perubahan suhu dan taburan hujan bagi tempoh 5 tahun dan 20 tahun dapat dikenalpasti. Analisis arah tumpuan burung hijrah membolehkan suatu lokasi yang berpotensi menjadi lokasi alternatif sekiranya berlaku perubahan iklim pada masa akan datang diperolehi. Melalui hasil analisis model yang dilakukan, peningkatan kepadatan burung hijrah sebanyak 4\% hingga 25\% bagi tempoh 5 tahun ditunjukkan di kawasan sekitar Sangga Besar, Teluk Kertang, Trong, sebahagian kecil kawasan di Pulau Trong Selatan, Sungai Tinggi dan Pulau Pasir Hitam. Namun mengalami penurunan sebanyak $4 \%$ hingga $44 \%$ bagi beberapa kawasan di Kuala Gula, Temerlok, Sungai Sepetang dan dikebanyakan kawasan Pulau Trong Selatan (Rajah 8)

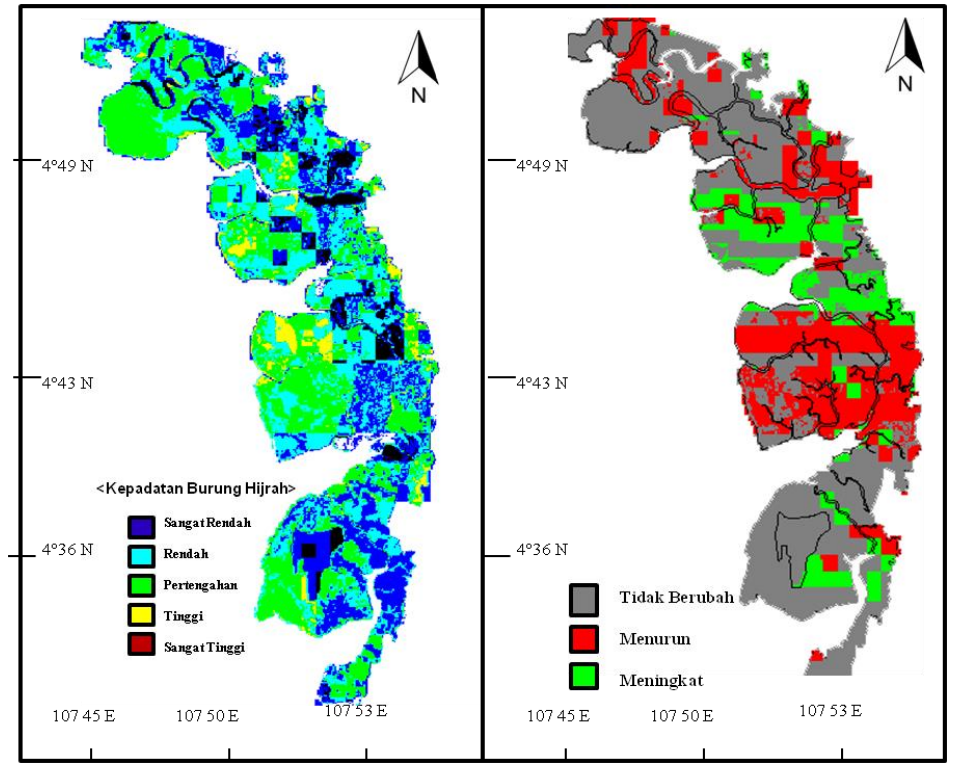

Rajah 8 Perubahan taburan burung hijrah bagi jangkamasa 5 tahun

Perubahan yang sedikit berbeza ditunjukkan selepas tempoh 20 tahun iaitu kawasan sekitar Trong, Pulau Trong Selatan, Temerlok dan juga Pulau Pasir Hitam menunjukkan penurunan kepadatan burung hijrah. namun begitu kawasan sekitar Sangga Besar, Teluk Kertang, Temerlok, Pulau Pasir Hitam dan Sungai Tinggi menunjukkan peningkatan kepadatan taburan burung hijrah bagi tempoh ini. terdapat juga kawasan yang mengalami penurunan secara berterusan dari tempoh 5 tahun sehingga 20 tahun iaitu sekitar Sungai Sepetang dan Sungai Selinsing yang sememangnya merupakan kawasan yang kurang dikunjungi oleh spesis burung hijrah (Rajah 9). 


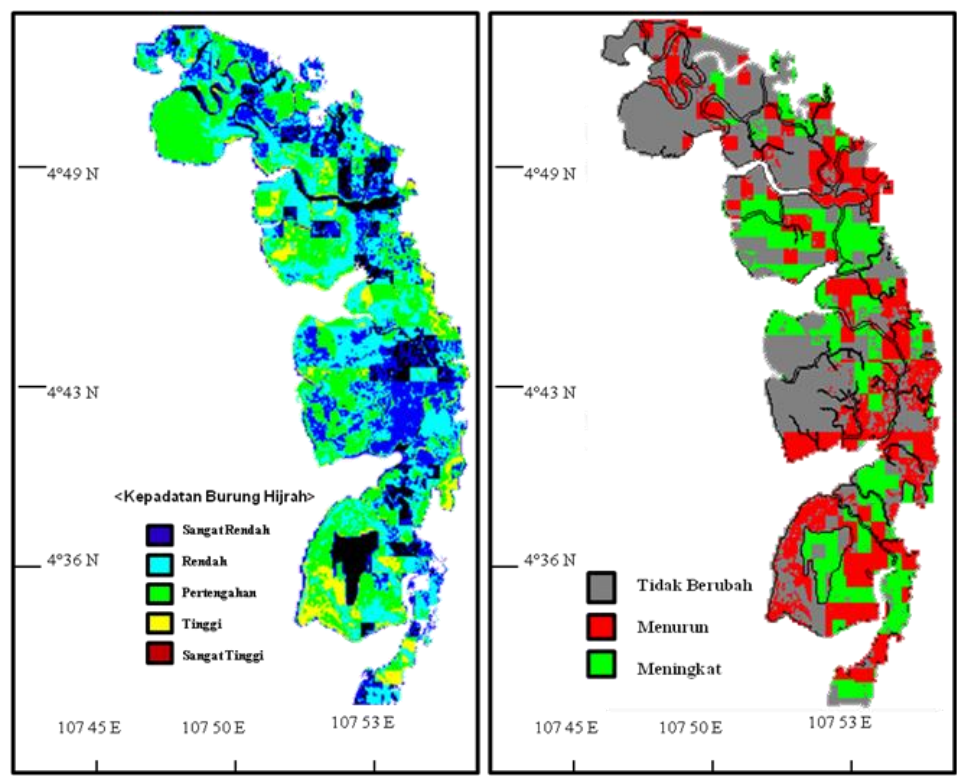

Rajah 9 Perubahan taburan burung bagi jangkamasa 20 tahun

Hasil analisis ini membantu agensi yang berkaitan seperti arah taburan burung hijrah dapat membantu Jabatan Perhilitan khususnya dalam mengenalpasti kawasan yang perlu dipelihara dan dipulihara bagi memastikan kedatangan burung hijrah yang berterusan. Maklumat yang diperolehi melalui model iklim ini mampu mengenalpasti kawasan yang berpotensi sebagai lokasi alternatif bagi habitat burung hijrah yang boleh digunakan oleh Jabatan Perhilitan yang dalam melaksanakan program pengurusan dan pemantauan burung hijrah secara lebih bersistematik.

Hasil kajian ini menunjukkan menunjukkan kebanyakan kawasan perlu dipelihara dan program pemuliharaan perlu bagi kawasan seperti Sungai Bahru, Sangga Kecil dan Trong yang terus mencatatkan penurunan selepas tempoh 5 tahun. Faktor yang menyebabkan penurunan ini juga perlu dikenalpasti. Kawasan yang kurang terjejas seperti Sangga Besar dan Kertang juga perlu diberi perhatian bagi memastikan lokasi ini mampu menyediakan keperluan hidup seperti makanan dan tempat tinggal yang secukupnya kepada burung hijrah (Rajah 10).

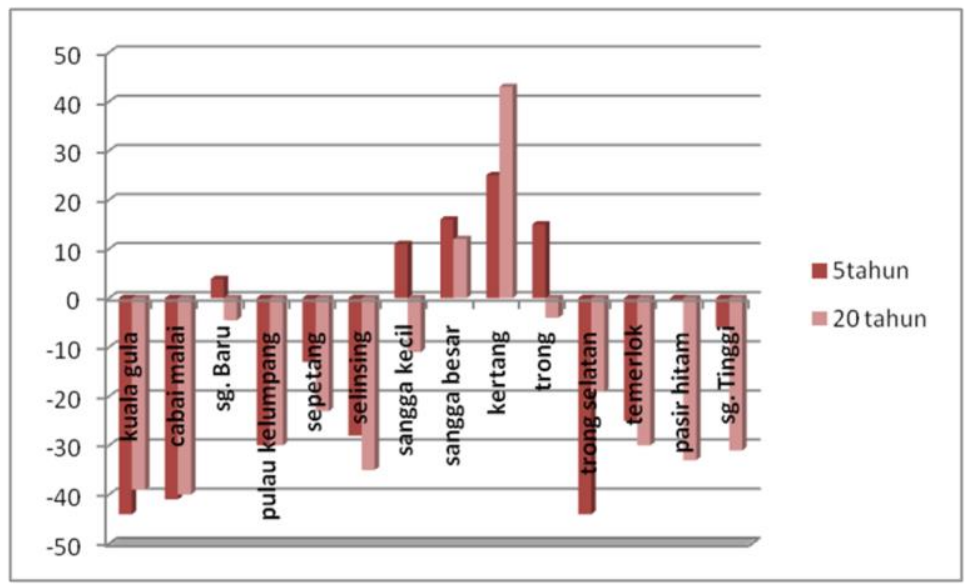

Rajah 10 Analisis penurunan dan peningkatan bagi kedatangan burung hijrah

\subsection{Corak Taburan Burung Hijrah}

Berasaskan pemodelan iklim pengaruh iklim terhadap kepadatan semasa dan masa akan datang bagi burung hijrah dapat ditentukan. Namun begitu, berasaskan hasil analisis yang diperolehi corak taburan burung hijrah tidak dapat ditentukan secara tepat. Dalam kajian ini, penggunaan statistik Moran I telah digunakan bagi membantu meramal keadaan corak taburan burung hijrah berasaskan model iklim yang dihasilkan bagi tahun semasa mahupun bagi jangkamasa 5 tahun dan 20 tahun akan datang.

Analisis yang dijalankan menggunakan kaedah Moran I menunjukkan menunjukkan critical region yang diperolehi adalah \pm 1.96 iaitu terkeluar dari sempadan kritikal yang menunjukkan bahawa taburan adalah tidak random. Dalam kajian ini, formula statistik Moran I digunakan bagi memastikan keseluruhan kawasan kajian yang dipecahkan mengikut piksel diambil kira (Rajah 11). 


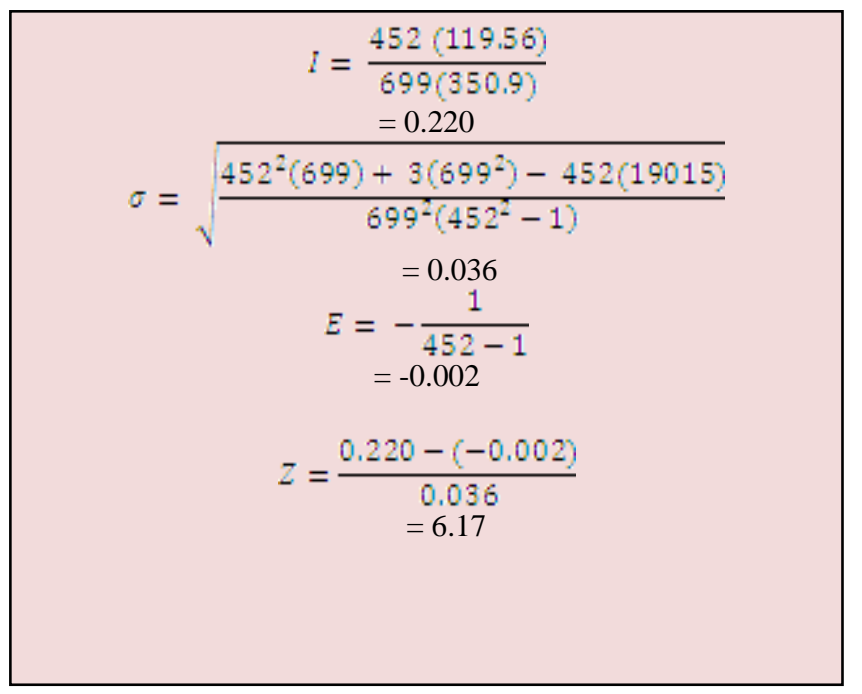

Rajah 11 Pengiraan nilai $i$ bagi menentukan corak taburan burung hijrah

Hasil analisis Moran I menunjukkan taburan burung hijrah adalah berselerak di sekitar Hutan Paya Laut Matang dan di sokong dengan hasil pemetaan yang dihasilkan oleh model iklim (Rajah 12)
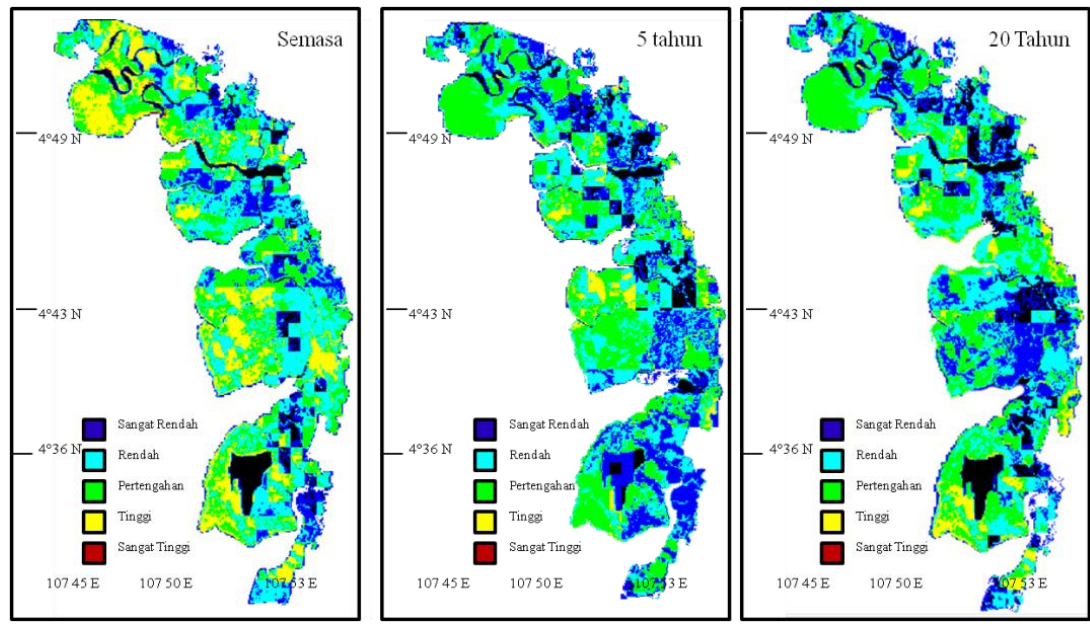

Rajah 12 Corak taburan burung hijrah yang berselerak

Hasil pemetaan menunjukkan sesuatu lokasi mempunyai pelbagai corak taburan burung hijrah yang berselerak iaitu tiada lokasi yang menjadi tumpuan khusus sebagai contoh beberapa kawasan menjadi tumpuan burung hijrah seperti Pulau Kalumpang, Pulau Trong dan Pulau Pasir Hitam.

\subsection{KESIMPULAN DAN CADANGAN}

Pemodelan suhu dan taburan hujan dilakukan dengan mengambil kira kepadatan taburan burung hijrah sekitar Hutan Paya Laut Matang yang berperanan untuk menunjukkan kesan setiap parameter terhadap pola taburan burung hijrah sekitar kawasan Hutan Paya Laut Matang. Pemodelan ini berperanan menunjukkan kesan iklim terhadap pola taburan burung hijrah sekitar kawasan kajian secara menyeluruh melalui hasil pemetaan dan analisis statistik. Pendekatan teknologi Penderiaan Jauh yang berasaskan piksel adalah sesuai diaplikasikan bagi menganalisis pengaruh parameter iklim yang menyeluruh dan tidak tertumpu kepada sesuatu sempadan kawasan sahaja. Beberapa data berasaskan piksel digunakan dalam kajian ini iaitu TRMM (data hujan) dan MODIS (data suhu) bagi membantu dalam menghasilkan analisis yang lebih jelas bagi mengenalpasti kesan suhu dan taburan hujan terhadap taburan burung hijrah yang tidak dapat ditunjukkan secara jelas dalam bentuk data titik. Hasil analisis juga disokong dengan pemetaan yang memudahkan interpretasi data dilakukan menggunakan aplikasi Sistem Maklumat Geografi (GIS).

Hasil analisis yang diperolehi daripada model ini menunjukkan kesan suhu dan taburan hujan bagi suatu sempadan kawasan yang sama adalah berbeza-beza. Keadaan ini menyebabkan taburan burung hijrah pada kepadatan yang berbeza-beza direkodkan bagi 
setiap stesen jaringan. Kajian ini juga meramal kesan suhu dan taburan hujan terhadap taburan burung hijrah pada jangkamasa 5 tahun dan 20 tahun akan datang. Perbezaan lokasi tumpuan habitat burung hijrah direkodkan melalui analisis ramalan yang dilakukan membolehkan pengenalpastian lokasi alternatif bagi habitat burung hijrah pada masa akan datang diperolehi.

Berasaskan pemodelan yang dilakukan membolehkan pelan pembangunan dilaksanakan dengan lebih berkesan dan mengambil kira keadaan persekitaran khususnya yang berkait rapat dengan iklim bagi menjamin kesejahteraan ekosistem setempat secara bersistematik dan berkesan. Selain itu, dalam usaha menjadikan kawasan sekitar Hutan Paya Laut Matang sebagai lokasi tarikan pelancongan melalui kedatangan burung hijrah pemodelan ini membantu memberi maklumat lokasi yang bersesuaian untuk pembangunan tanpa menjejaskan serta merosakkan kawasan yang menjadi tumpuan spesis burung hijrah.

Selain itu, maklumat berkaitan burung hijrah seperti jenis spesis, keperluan habitat, masa kedatangan dan kesan perubahan persekitaran terhadap spesis burung hijrah dapat diberikan kepada pengunjung yang datang ke Hutan Paya Laut Matang bagi melihat dan memahami secara dekat spesis burung hijrah yang ternyata unik dan mempunyai potensi tersendiri dalam ekopelancongan. Keadaan ini membantu meningkatkan kualiti dan potensi bidang pelancongan yang baru diketengahkan di kawasan ini sebagai suatu aktiviti yang menarik dan lebih berinformatif untuk pelbagai lapisan masyarakat.

Hasil analisis berasaskan kepadatan burung hijrah sekitar kawasan Hutan Paya Laut menunjukkan kesemua parameter kajian yang dipilih dan diberi penekanan dalam kajian ini memberi pengaruh pada kadar yang berbeza dan saling berkaitan antara satu sama lain dalam penyediaan habitat yang diperlukan oleh burung hijrah yang datang berhijrah ke Malaysia khususnya ke kawasan Hutan Paya Laut Matang bagi tempoh sembilan bulan (September hingga April) setiap tahun. Kawasan seperti Pulau Kalumpang, Pulau Sanggar Besar, Kuala Gula, Cabai Malai dan Trong menunjukkan kawasan yang menjadi tumpuan utama burung hijrah yang mampu menyedikan keperluan habitat bagi spesis burung ini.

Perubahan keadaan iklim tempatan berkait rapat dengan isu pemanasan global menjadi tumpuan diperingkat antarabagsa yang memberi impak negatif terhadap migrasi burung hijrah diseluruh dunia termasuk di Malaysia. Peningkatan iklim terutamanya berkaitan suhu dan taburan hujan menjadi elemen utama dalam mempengaruhi keadaan iklim dunia memberi kesan jangka panjang yang membimbangkan kerana perubahan yang kecil terhadap kedua-dua elemen ini memberi kesan kepada keadaan persekitaran yang secara tidak langsung memberi impak kepada kepadatan kedatangan burung hijrah yang direkodkan.

Hasil analisis ini memberi maklumat berguna kepada agensi berkaitan yang memantau dan mengurus kedatangan burung hijrah sekitar kawasan Hutan Paya Laut seperti Jabatan Perhilitan dan Jabatan Perhutanan. Kawasan seperti Sangga Kecil, Sanggar Besar, Kertang dan Trong merupakan kawasan yang dikenalpasti berpotensi menjadi lokasi alternatif sebagai habitat burung hijrah pada masa akan datang sekiranya berlaku gangguan atau kemusnahan akibat perubahan iklim terhadap kawasan persekitaran Hutan Paya Laut Matang.

Rujukan

Allen, A.P., O'Connor, R. J. (2000). Interactive Effects Of Land Use And Other Factors On Regional Bird Distributions.Journal Of Biogeography, 27, 889900 .

Alongi, D.M., ASasekumarb, F Tirendia, P Dixona, (1998). The Influence Of Stand Age On Benthic Decomposition And Recycling Of Organic Matter In Managed Mangrove Forests Of Malaysia.Journal Of Experimental Marine Biology And Ecology, 225(2),197-218

Cotton, P. A. (2003). Avian Migration Phenology And Global Climate Change.Proceedings Of The National Academy Of Sciences, 100(21), 12219-12222

Galbraith, H., Jones, R., Park, R., Clough, J., Herrod-Julius, S., Harrington, B., Page, G. (2005). Global Climate Change And Sea Level Rise Potential Losses Of Intertidal Habitat For Shorebirds. USDA Forest Service Gen. Tech. Rep. PSW-GTR-191.

GauthreauxJr,S.A., Belser, C.G.(2003).Radar Ornithology And Biological Conservation.The Auk, 120(2), 266-277.

Gorokhovich, Y., Voustianiouk, A. (2006).Accuracy Assessment Of The Processed SRTM Basedelevation Data By CGIAR Using Field Data From USA And Thailand And Its Relation To The Terrain Characteristics. Remote Sens. Environ, 104, 409-415.

Howes,J., Bakewell,D., Yus Rusila Nor. (2003). Panduan Studi Burung Pantai. Indonesia :Wetland International, No ISBN: 979-95899-2-4.

Jamaluddin Md. Jahi.(2009). Pembangunan Pelancongan Dan Impaknya Terhadap Persekitaran Fizikal Pinggir Pantai. Malaysian Journal Of Environmental Management, 10 (2), 71-87.

Moore, F.R., Woodrey, M.S., Buler, J. J.,Woltmann, S., Simons,T.R. (2005). Understanding The Stopover Of Migratory Birds: A Scale Dependent Approach.USDA Forest Service Gen. Tech. Rep. PSW-GTR-19.

Osborne, P. E., Alonso, J. C., \& Bryant, R. G. (2001). Modelling Landscape-Scale Habitat Use Using GIS And Remote Sensing: A Case Study With Great Bustards. Journal Of Applied Ecology, 38(2), 458-471.

Peterson, A.T. (2001). Predicting Species' Geographic Distributions Based On Ecological Niche Modeling. The Condor, 103(3), 599-605.

Rabus, B., Eineder, M., Roth, A., \&Bamler, R. (2003). The Shuttle Radar Topography Mission A New Class Of Digital Elevation Models Acquired By Spaceborne Radar. Journal Of Photogrammetry And Remote Sensing, 57, 241-262.

Sanz, J. J., Potti, J., Moreno, J., Merino, S., \& FRÍAs, O. S. C. A. R. (2003). Climate Change And Fitness Components Of A Migratory Bird Breeding In The Mediterranean Region. Global Change Biology, 9(3), 461-472.

Scott, J. M., Davis, F., Csuti, B., Noss, R., Butterfield, B., Groves, C \& Wright, R. G. (1993). Gap Analysis: A Geographic Approach To Protection Of Biological Diversity. Wildlife Monographs, 3-41.

Shao, G., Wu, J. (2008). The Accuracy Of Landscape Pattern Analysis Using Remote Sensing Data.Landscape Ecology, $23,505-511$.

Smith, C. R., De Leo, F. C., Bernardino, A. F., Sweetman, A. K., \& Arbizu, P. M. (2008). Abyssal Food Limitation, Ecosystem Structure And Climate Change.Trends In Ecology \& Evolution, 23(9), 518-528.

Taher Buyong.(2006). Spatial Statistics for Geographic Information Science. Malaysia: University Teknologi Malaysia Press.

Tankersley, R., Jr.,Orvis, K. (2003). Modeling The Geography Of Migratory Pathways And Stopover Habitats For Neotropical Migratory Birds. Conservation Ecology, 7(1): 7.

Wang, Y., Finch, D.M. (2002). Consistency Of Mist Netting And Point Counts In Assessing Landbird Species Richness And Relative Abundance During Migration. The Condor, 104(1), 59-72. 